\title{
O projeto brasileiro do Código de Direito de Autor e Direitos Conexos.*
}

\author{
Antônio Chaves \\ Catedrático de Direito Civil e Professor \\ Contratado de Direito Comparado da Facul- \\ dade de Direito da Universidade de São Paulo. \\ Membro da Comissão Jurídica e de Legislação \\ da "Confedération Internationale des Societés \\ d'Auteurs et Compositeurs"
}

\section{Parte I.}

\section{Prolegômenos.}

Breve história do Projeto.

"Habent sua fata propositiones legum.

Os próprios projetos de lei não se subtraem à contingência de súditos da surda e cega deusa Fortuna.

$\mathrm{E}$ antes que alterações profundas tenham lugar em um projeto de Código de Direito de Autor que, em princípio do ano passado, foi apresentado ao Govêrno Brasileiro, e que talvez, não logre prosseguir seu caminho, parece-me oportuno o momento, e não poderia ser mais adequado o lugar que generosamente me oferece esta Revista, para fazer um relatório sumário da atividade que, com relação à matéria, se desenvolveu no Brasil nestes últimos tempos.

* O presente artigo foi escrito em italiano, a convite da Revista Il Diritto di Autore, órgão oficial da "Società Italiana degli Autori ed Editori", com sede em Roma, que anuíu na sua concomitante divulgação no Brasil. A versão esteve a cargo do acadêmico de direito Eduardo Lobo Botelho Gualazzi. 
O Diário Oficial da União de 16 de junho de 1967 publicava, em uma "separata" de 39 páginas, um anteprojeto de Código de Direito de Autor e Direitos Conexos, fruto da cultura especializada e da sensibilidade do Desembargador do Tribunal de Justiça de Brasília MrLton Sebastião Barrosa.

Precedido de minuciosa "Exposição de Motivos", p. 1-15, o anteprojeto constituíu-se de 351 artigos divididos em dezesseis títulos, a maior parte dos quais subdivididos em diversos capítulos:

I - Direito de autor. Conteúdo. Atributos.

II - Da obra intelectual-autoral.

III - Da duração do direito de autor. Título da obra.

IV - Dos atributos do direito de autor.

V - Da transmissão do direito de autor.

VI - Limites do direito de autor. Fontes de origem.

VII - Domínio público remunerado.

VIII - Regimes especiais.

IX - Do direito do artista, intérprete ou executante.

$\mathrm{X}$ - Do direito do produtor fonográfico.

XI - Do direito dos organismos de radiodifusão (sonoros e visuais).

XII - Do registro.

XIII .- Das associações literárias, artísticas e cientificas. Das sociedades de direitos de autor ou conexos.

XIV - Do Conselho Nacional de Direitos de Autor e Conexos (Condac).

XV - Das violações. Das sanções. Medidas cautelares. Da competência e procedimento.

Título final - Disposições finais e transitórias.

Em data de 23 de maio de 1967 foi nomeada pelo Ministro da Justiça uma comissão revisora composta pelo Pre- 
sidente, Ministro do Supremo Tribunal Federal, Professor CÂndido Motta Filho, pelo Relator, Desembargador Mrlton Sebastião Barbosa, e pelo autor destas linhas.

Após numerosíssimas e exaustivas sessões que se prolongaram até o mês de agôsto do ano passado, a comissão se cindiu em duas partes.

Por um lado, o Relator Geral e eu mesmo, que oferecemos um Projeto de 198 artigos, divididos em três partes:

I - Direito de autor (Generalidades, Atributos, Limites);

II - Transmissão (Causa-mortis e inter-vivos);

III - Defesa (Orgãos, Medidas Cautelares, Sanções).

Por seu turno, o Ministro Cândido MotTa FiLHo apresentou um substituto de 89 artigos, dividido em 12 capitulos:

I - Dos direitos de autor;

II - Da edição;

III - Da representação dramática;

IV - Da obra de arte plástica;

V - Da obra fotográfica;

VI - Da obra jornalística ou periodística;

VII - Da obra do artista, intérprete ou executante;

VIII - Dos direitos conexos;

IX - Da sociedade;

$\mathrm{X}$ - Das sanções;

XI - Conselho Nacional dos Direitos de Autor e Conexos;

XII - Disposições finais e transitórias.

Foi com grande surprêsa e profunda mágoa que os outros membros da comissão tiveram a notícia de haver perdido o apôio do Ministro CÂndido Motta Filho, cujo prestígio haveria certamente facilitado a aprovação do projeto. 
Mas não pudemos aceitar a posição doutrinária de Sua Excelência.

Qualquer sã remodelação legislativa da nossa matéria não poderá prescindir do ponto de partida de um seguro apôio ao autor da obra intelectual.

Proteger em primeiro lugar aquêle que produz, depois aquêle que reproduz, mais do que uma norma de elementar bom senso, é o caminho que parece indicar-nos a própria mãe natureza.

Se é verdade que no mundo inteiro se delineia cada vez mais nitidamente o fenômeno da existência de "grupos de pressão" que desenvolvem uma incansável atividade em prejuizo do autor e dos próprios empresários, em virtude do conseqüente rebaixamento do nivel da produção literária e artística, é por outro lado dever indeclinável dos juristas, convocados a prestar sua obra, quando queiram realmente dar uma contribuição duradoura, resistir obstinadamente a qualquer pressão, a fim de estabelecer aquêle equilíbrio que apenas a lei, através de disposições e providências oportunas, está em condições de fixar.

Ora, o exame mesmo rápido do substitutivo convence que, embora em grande parte transcreva simplesmente o Projeto, talvez desapercebidamente, presta-se, em numerosos dispositivos, ao jôgo dêstes interêsses.

Assim, para citar apenas alguns exemplos:

-- não proíbe "representações teatrais", independentes do consentimento do autor, dificilmente conciliáveis com o "recesso familiar" a que alude o art. 20;

- admite a transcrição, com dispensa de autorização, de trechos de obras alheias, sem garantir, todavia, a retribuição, como faz o Projeto, no art. $44, \S 3^{\circ}$;

- estende excessivamente (art. 22, XII), a liberdade de utilização de obras literárias e musicais para fins de demonstração comercial, inconveniente em que não incorre o art. 57 do Projeto; 
- demonstra maior benevolência quanto aos interêsses do editor do que quanto aos do autor (art. 29 a 30), ao passo que o Projeto harmoniza perfeitamente, no art. 76, a posição recíproca de ambos;

- concede desmedida proteção ao produtor fonográfico nos arts. 58 e 60, em contraste com a orientação do Projeto, que procura tutelar os direitos dos autores e dos artistas;

- remete a repressão das violações ao Código Penal, que outra coisa não faz senão repetir o que dispunha o Código Penal de 1940, em forma ainda mais atenuada.

O substitutivo, em suma, em nada aperfeiçoa as leis em vigor.

Deveria prevalecer o ponto de vista da maioria dos membros da Comissão.

Mas justamente porque não nutro ilusões acêrca dos efeitos da perda do apôio de uma personalidade tão prestigiosa, venho a público, pela vez primeira, não para recriminar tantos meses de esfôrço provàvelmente perdidos, mas com a esperança de que o Projeto possa oferecer alguma inspiração aos outros especialistas, particularmente das demais Nações da América Latina, atormentados pelo desejo de aperfeiçoamento da própria legislação.

$O$ essencial é ter um ponto de partida, um figurino mais de acôrdo com o nosso tempo, seja mesmo. em papel de jornal, de modo que, com tesouras e goma arábica, se possa eliminar a excesso e acrescentar o que falte, a fim de que o resultado possa ser modelado ao corpo a que se destine.

\section{Por quê um Código e não simplesmente uma lei sôbre o direito de autor?}

Parecerá talvez demasiado ambicioso o nome de Código, tanto mais que a grande lei italiana ${ }^{\circ} 633$, de 22 de abril de 1941, com os seus 206 artigos, a alemã, de 9 de setembro de 
1965, com os seus 143 , a lei francêsa $n^{0} 57-298$, de 11 de marco de 1957 , com os seus 82 , a mexicana de 4 de novembro de 1963 , com os seus 160 , se contentam com a modesta e tradicional designação de lei.

A explicação do Desembargador Milton Sebastião Barbosa, na sua Exposição de Motivos, é exaustiva ao demonstrar que o seu trabalho não se limitou a uma simples consolidação dos textos existentes, mas teve por finalidade uma sistematização de tôda a matéria, incorporando as mais recentes conquistas dos povos cultos, harmonizandoas com a legislação e com as necessidades brasileiras, de tal modo que, com realismo, o nôvo diploma legislativo pudesse atender às exigências do mundo contemporâneo.

"Pela sua complexidade, pela sua expansão, em virtude do progresso inusitado dos meios de comunicações, disciplinar a obra intelectual, o direito do autor e os direitos correlatos, surgidos em razão dêste progresso, importou em uma reforma ampla e substancial das leis vigentes e da forma da sua aplicação...

É que, dada a evolução das relações jurídicas a serem disciplinadas, oriundas da atividade intelectual, surgiu, não diremos um direito nôvo, mas um direito cuja expansão e peculiaridade obriga o Estado a dar-lhe um tratamento específico. .

Lembra que a Constituição de 1946 já dispunha no art. 174, como faz a atual no art. 180, que a proteção à cultura constitui um dever do Estado, e acrescenta:

"Por isso, a lei reguladora dos direitos de autor e dos que lhe são correlatos, há de constituir um sistema, não só de disposições de proteção às atividades intelectuais, mas, também, cuidar dos meios capazes de assegurar esta proteção. Ao mesmo tempo em que estende a sua ação protetora a estas ati- 
vidades, atendendo às suas ressonâncias, a lei deverá estabelecer regras unificadoras, imperativas, de fácil fiscalização, resguardando, também, os interêsses dos usuários das obras intelectuais, dos que as divulgam. dos que nela buscam a lição ou o entretenimento."

Transcreve André Huguet, L'Ordre Public et Les Ciontrats d'explotation dı Droit d'Auteur, Paris, 1962, p. 2: “Il est à presumer que toutes les règles destinées à la défense des auteurs sont d'ordre public", e o comentário que exara Rení SAvatier, prefaciando a mesma obra:

“L'une des principales innovations de la loi de 11 mars 1957 - peut être la plus importante a donc été d'enfermer les contrats relatifs à ce droit d'explotation de l'auteur en des règles d'ordre public...

Et, il souligne comment le désir du législateur, édictant ces règles d'ordre public, a été d'assurer, par elles, une meilleure protection de l'auter, à l'interieure d'affaires où il n'existe pas d'équilibre quant à la experience des affaires et au pouvoir économique, entre les Muses et Mercure."

Demonstra ainda que as disposições das mais recentes leis germânicas e peruanas, e do decreto-lei português $\mathrm{n}^{\circ}$ 46.980, de 27 de abril de 1966, claramente deixam transparecer o alto senso de ordem pública de suas disposições.

Nem se pode deixar de acrescentar que o Govêrno Brasileiro, que sempre se interessou por sua importante tarefa de codificação, está atualmente empenhado num amplo trabalho de renovação de seus mais importantes Códigos: Código Civil, Código Penal, Código Penal Militar, Código do Trabalho e respectivos Códigos Processuais, Código das Execuções Criminais, Lei Geral de Aplicaçâo das Normas Juridicas, Código da Navegação, Código da Propriedade In- 
dustrial, alguns em vias de publicação, outros já publicados para efeitos de discussão e outros, finalmente, promulgados.

Não poderia, certamente, o direito de autor, tão importante numa nação ansiosa por progresso e afirmações, e com possibilidades ilimitadas em todos os campos, não acompanhar essa tendência, em que deveria, isto sim, ocupar uma posição prioritária.

Filipro Vassali, no Relatório Geral apresentado em Roma em julho de 1950 , e transcrito nas Actes du Congrés International de Droit Privé, $2^{\circ}$ vol. 1951, e na Revista Forense, Rio de Janeiro, v. 148, p. 50-57, aludia ao estranho fenômeno que desponta nas mais diversas épocas da História: as recriminações ao Estado de Direito têm, ordinàriamente, sua origem na desordem em que se encontram as fontes do direito, a incerteza das leis, sua multiplicidade, sua falta de clareza, suas contradições, a insuficiência de pontos de referência, sua confusão, muito mais que no próprio valor das leis, na sua capacidade de harmonizarem-se com as necessidades, os gostos, o bem-estar e o progresso dos indivíduos, que são obrigados a respeitá-las.

Bem se compreende, nestas condições, que o Projeto, não descuidando da tradição histórica, procure estabelecer uma sã e corajosa política baseada em três fundamentos:

1. conservação de tudo aquilo que a legislação em vigor possa oferecer de útil;

2. incorporação de novos elementos abundantemente oferecidos pela jurisprudência nacional e internacional, pelas leis estrangeiras e pelos tratados internacionais;

3. reestruturação total por meio de uma nova construção orgânica, que lhe confira verdadeiramente a dignidade de "Código".

"Continuidade e inovação", poderia ser a divisa a insculpir-se em seu escudo: uma preparação que, sem antecipações, esteja destinada a aplainar o caminho para novos desenvolvimentos. Aproveitar o material herdado das cons- 
truções antigas, reuní-lo num nôvo complexo de normas realmente moderno, e considerar as instituições atuais com "olhar evolucionista".

A não se obter, pelo menos em parte, a satisfação dessa finalidade, tanto valerá resignar-mo-nos a deixar tudo como está, à espera de tempos melhores.

\section{Idéias fundamentais.}

a) Autorização prévia.

Não basta, contudo, que um Código, para que seja Código, tenha êste nome: precisa merecê-lo, para o que várias condições devem ser satisf eitas.

Em primeiro lugar, deve basear-se sôbre a legislação em vigor no país ao qual se destine.

Certamente, tanto no esbôço preliminar, como no projeto, não era possivel fazer abstração das mais importantes conquistas da legislação das nações mais progressistas em nossa especialidade.

Mas resultaria vão e falso o esfôrço que não procurasse atingir no complexo legislativo pátrio os elementos fundamentais, enriquecendo-os com a contribuição de alguma idéia no entretempo amadurecida.

No momento da publicação do anteprojeto podiam ser enumerados, até 26-4-1967, nada menos que 268 atos legislativos, direta ou indiretamente relativos ao direito de autor.

Entre êstes e outros posteriores, são dez os mais importantes:

1 Art. 649-673 do Código Civil (Lei $\mathrm{n}^{\circ}$ 3.071, de 1-1916);

2. Decreto 4.790, de 2-1-1924: define os direitos de autor;

3. Decreto 5.492, de 16-7-1928, Lei Getúlio Vargas e respectivo 
4. Regulamento, decreto 18.527, de 10-12-1928;

5. Arts. 184 e 185 do Código Penal, Decreto-lei n. 2.848, de 7-12-1940;

6. Decreto-lei 20.493, de 24-1-1946, que aprova o Regulamento do Serviço de Censura de Diversões Públicas do Departamento Federal de Segurança Nacional;

7. Lei 2.415, de 9-2-1955, que dispõe sôbre concessão de permissão autoral para a realização de representações e execuções públicas e para as transmissões por rádio ou televisão;

8. Decreto 1.023, de 17-5-1962, que estende aos Estados e Territórios a legislação em vigor no Distrito Federal;

9. Lei 4.944, de 6-4-1966, que concede proteção aos artistas, produtores de fonogramas e organismos de radiodifusão e o seu

10. Regulamento, decreto $\mathrm{n}^{\circ}$ 61.123, de 1-8-1967.

Sem grave prejuízo não poderá ser abandonado o sistema atual que reconhece ao autor o direito exclusivo de conceder licenças e autorizações prévias para qualquer execução ou representação de tôda composição musical, tragédia, drama, comédia, ou outra produção de espetáculos públicos por meio de pagamento de entrada, estabelecido no Brasil desde 2-1-1924, e sucessivamente desenvolvido e adaptado aos novos sistemas mecânicos e da transmissão.

Com certeza a idéia poderá ser aperfeiçoada.

Recorde-se, porém, que Jean Vilbois, Du Droit Public Payant en Matière de Droit d'Auteur, Sirey, Paris, 1929, observava, à p. 492, que uma proteção preventiva bem organizada deve dispensar recorrer-se à repressão, salvo em casos muito raros.

E faz um rol dos pouquíssimos países em que o sistema é praticado: Itália, Noruega, Dinamarca e Brasil, embora sendo reclamado por outras nações e entidades de autores.

Conclui que, "sem isso, a proteção do direito de autor permanecerá sempre ilusória”. 


\section{b) Proteção da obra.}

Proteção do autor ou da obra?

Eis uma indagação que foi levantada no seio da Comissão de Revisão.

Os dois autores do Projeto chegaram à conclusão de que tão sòmente a tradição faz conservar o vêzo de dizer-se que as leis de direito de autor protegem o autor: protegem, na verdade, a obra.

O que diz o art. $1^{\circ}$ da lei italiana, fonte e inspiração de tantas outras?

"Sono protette... le opere dell'ingegno di carattere creativo..."

Faz um elenco das obras "compreendidas na proteção" (art. 2) e em sucessivas seções se refere à proteção da utilização econômica para determinadas categorias de obras e assim por diante.

É certo que a lei francesa concede a proteção, de resto como tôdas as outras, a "l'auteur d'une oeuvre de l'esprit", mas "du seul fait de sa création", e não pode deixar de fa zer, no art. $3^{\circ}$, a enumeração das obras intelectuais que considera.

Se a proteção fôsse verdadeiramente do autor, e não da obra, preocupar-se-ia a lei com a pessoa dêle, com a assistência que certamente merece (mas por outro título), em virtude de acidente, de doença, de desemprêgo, com a assistência familiar, higiênica, demográfica, proteção e educação dos filhos, com a perda de retribuições, com sua veIhice, com a aposentadoria, etc., etc., matéria tôda estranha ao nosso domínio.

Se a proteção fôsse verdadeiramente do autor, cairia na contradição de protegê-lo ainda quando não fôsse capaz, ou mais capaz, de produzir obra alguma, e deveria assistir também aos autores de obras absolutamente insulsas, medíocres, sem qualquer originalidade ou personalidade, o que seria um verdadeiro absurdo e um obstáculo intransponível. 
Se conseguissemos reconhecer, uma vez por tôdas, que a lei, na realidade, protege a obra, e, apenas por via reflexa, o autor, obteríamos resultados que superariam em muito o que se poderia pensar seja apenas uma questão de terminologia.

Liberar-se-ia o codificador do complexo de todos aqueles compromissos, preocupações e cuidados que tanto desnaturam as disposições relativas ao direito de autor, que, em última análise, não são mais que uma enumeração minuciosa, fastidiosa e ineficaz das reivindicações e dos privilégios de autor. Enquanto constituir a sua própria pessoa a finalidade da norma, as disposições perderão a sua fôrça vital, a sua eficácia, a sua própria razão de ser.

Não compreenderá o cidadão comum porque deva ser punido por ter difundido em público u'a música gravada num disco e julgará inconcebível qualquer punição quando a violação do direito represente apenas um dano potencial de algum centavo para o autor.

Difunda-se, todavia, a convicção de que a violação é da obra, propale-se a certeza de que êste ato, por si próprio, representa não apenas uma lendária violação ao direito patrimonial do autor, mas um delito contra a própria obra, onde quer que seja transmitida ao público sem autorização, e a distorção será eliminada, provocando, em resultado, o benefício para o autor de uma proteção efetiva, real, atuante, e não meramente teórica.

Na proteção do autor se deveria atender a um critério essencialmente subjetivo, reportando-nos, diuturnamente, à sua personalidade, à sua sensibilidade, às suas simpatias ou antipatias.

$\mathrm{Na}$ proteção da obra abraçaremos um critéric mais plausivel, mais objetivo, mais verdadeiro, atribuindo-se a pessoas experimentadas a tarefa de verificar, sem excesso de amor próprio, se ocorreu realmente uma violação passivel de sanção. 
E basta considerar a tendência legislativa sempre mais vívida no sentido de conceder permissões para adaptações à radiodifusão, à cinematografia, à televisão, para compreender-se que, quer se queira ou não, é nesta direção que se esboça o futuro.

Se, finalmente, o que se protege é o direito de autor, năo obedece ao rigor da lógica especificar as obras tuteladas.

$\mathrm{E}$, ao final das contas, é a obra, e não o autor, que interessa primordialmente à coletividade. Se o que se procura defender é a produção espiritual, se é a obra que nasce, projeta-se, vive e perpetua-se, adquirindo personalidade própria, quase que dissociando-se do autor, tanto é verdade que, malgrado o reconhecimento da paternidade, admite-se até mesmo a possibilidade de expropriação, e transcorridos alguns decênios da morte do autor seus sucessores não podem reivindicar qualquer direito patrimonial, é verdadeiramente a obra, não o autor, que se quer proteger.

Eis porque o projeto, em plena coerência, antepondo a obra ao autor, esclarece sua posição no final do artigo primeiro, que deverá inspirar seu inteiro desenvolvimento:

“A criação de uma obra intelectual, seja qual fôr seu gênero, forma de expressão e destinação, confere ao autor os direitos morais e pecuniários cuja defesa as normas de ordem pública dêste Código asseguram."

Em rigor de lógica, por tal motivo, sua denominação deveria ser Código de Obra Intelectual.

c) A obra dos artistas intérpretes e executantes.

Outro problema grave que o Projeto não hesitou enfrentar é o relacionado à proteção dos artistas intérpretes e executantes.

São b€m conhecidas as controvérsia acêrca da questão de constituir ou não, sua criação artística, uma obra tutelável aos fins da lei sôbre direito de autor. 
Mas, à medida em que se multiplicam as modalidades de gravação das obras literárias e musicais, não se pode negar que, embora como obra derivada ou de segunda mão, sua interpretação dê lugar a uma versão nova e pessoal, que não pode ser subtraída à proteção que não se recusa a obras que, como as fotográficas, exigem, geralmente, menor contribuição pessoal.

Limpida intuição houveram acêrca da matéria ETTORE ValÉrio e Zara Algard, Il Diritto d'Autore, Milão, Giuffrè, 1943, p. 233:

"Il compositore di musica non può dare alla sua opera la forma suscettibile di produrre sul pubblico l'emozione estetica ricercata. A questo effetto, il concorso di un altro artefice è assolutamente necessário; il concorso dell'artista esecutore.

Ora, non si può negare che il contributo di quest'ultimo all'opera comune presenti il carattere personale che determina la creazione artistica."

"Jusqu'à ces annés dernières," - acrescentam R. Platsant e M. Saporta, Les Droits Connexes au Droit d'Auteur ou Voisins du Droit d'Auteur, in Juris Classeur de la Propriété Littéraire et Artistique, fasc. 5, 1953, no 43 - "nul ne songeait à assimiler auteurs et artistes éxécutants. Il semblait que leurs fonctions respectives s'opposaient nettement l'une à l'autre."

E malgrado venham a afirmar depois, sem muita convicção, que o artista executante não desfruta em França, de acôrdo com a jurisprudência, de um direito de autor, não podem não reconhecer que "l'auteur crée l'oeuvre, l'artiste éxécutant l'exprime. Le premier a l'apanage de l'originalité esthétique, le second traduit fidèlement l'oeuvre qu'il éxécute."

Muitos outros testemunhos poderiam ser invocados a êste mister. 
Valha, por todos, aquêle de Valério de Sanctis, Presidente da Comissão Jurídica e de Legislação da Confederação Internacional da Sociedade de Autores e Compositores, no relatório apresentado em 1954, ao IV Congresso internacional de Direito Comparado, da Academia de Direito Comparado de Haia, "Rivista del Diritto Commerciale", Vallardi, Milão, v. 53, 1955, p. I.

Após um exaustivo exame dos dados relativos à proteção, no plano nacional de diversos países, das produções dos artistas executantes, dos fabricantes de fonogramas e dos organismos de difusão, demonstra "l'insufficienza della protezione e, sopratutto, l'incertèzza dei legislatori nazionali circa l'oggetto e la natura di questi nuovi diritti, circa il contenuto della protezione e i collegamenti coi diritti concorrenti e specie coi diritti degli autori, allorquando l'esecuzione, la registrazione e l'emissione riguardano un'opera dell'ingegno legalmente protetta."

Verifica que a tendência de separar a regulamentação do direito de autor da dos direitos vizinhos se deve à exigência de alguns interêsses industriais e ao mesmo tempo a razões de ordem psicológica e de organização, pelo que diz respeito aos autores e aos artistas executores e proclama que a solução do problema pelas leis austríaca e italiana,

“isto é, aquela de distinguir a proteção do direito de autor e dos direitos vizinhos em razão da diferente natureza do título justificativo, do objeto e das exigências da proteção e do fato que os novos direitos podem dizer respeito a produções e manifestações não protegidas pelo direito de autor (acontecimentos esportivos, fatos do dia, etc.), todavia, as regras de proteção do mesmo texto legislativo, possa ser a mais sábia. Ela tem a vantagem de regular, concomitantemente, direitos que têm o mesmo suporte material, o mesmo corpus mechanicum, e que são estreitamente ligados no plano 
econômico e contratual. Os principios da proteção poderiam assim amparar-se e equilibrar-se legislativamente."

E com indiscutível bom senso chega à conclusão de que o regulamento, num mesmo texto, das três categorias de direitos vizinhos, é plenamente justificado,

"mentre la mancanza di qualsiasi collegamento tra la regolamentazione di questi diritti e il diritto di autore dell'opera eseguita, registrata, radiodiffusa, potrebbe causare serie difficoltà nello sfruttamento dell'opera realizzata. Per questi motivi, la regolamentazione di codesti diritti nello stesso testo di legge, per quanto concerne le legislazioni nazionali, e con disposizioni di collegamento, per quanto concerne il campo della protezione internazionale, potrebbe, ritengo, rendere più efficace e meno complicati, nell'interesse dei vari titolari dei diritti stessi e sopratutto dei terzi."

A idéia da proteção do direito de autor, como do artista intérprete e executante, na mesma lei, começa a inserir-se com a lei mexicana de 4-1-1963 e com a argentina, a colombiana, a paraguaia, a salvadorenha e uruguaia.

Não se compreende, nem se pode admitir, numa lei verdadeiramente moderna, que a proteção ao artista intérprete deva ser remetida a um texto legal diverso do relativo ao autor.

Persistir em semelhante posição resultaria em prejuizo de ambos os grupos interessados, vale dizer, em dano para os próprios autores.

Ao menos no Brasil - e o fenômeno não pode ser diferente alhures - mostram-se os artistas muito mais dinâmicos e ativos na defesa de seus direitos. Já usufruem de u'a maior comunicabilidade, de maior penetração junto ao gran- 
de público e com mais desembaraço estão em condições de obter facilidades e proteção às suas reivindicações: o que é tanto mais perigoso porquanto, por outro lado, são prêsa mais fácil das lisonjas dos empresários, em geral.

A perpetuar-se esta cisão do âmbito legislativo - e recorde-se que os artistas já obtiveram importantíssimas vitórias também no setor internacional - poderá sobrevir uma inversão de posições, com grande prejuízo para a harmonia dos interêsses comuns.

Amadeo Giannini explica em Il Diritto dello Spettacolo, Jandi Japi, Roma, 1959, p. 427, como é plenamente conciliável o direito de autor $e$ o do intérprete.

Por que não procurar harmonizar amplamente os interêsses em um só diploma legal e estender, quiçá, a mesma conquista ao setor das convenções internacionais?

Reconhecida a prioridade do autor em sua qualidade de criador, mas admitida, ao mesmo tempo, a proteção subsidiária à obra do artista, ter-se-á conjugação, não dispersão de fôrças, união, não luta, através de uma regulamentação cuja amplitude tornará muito mais difícil, contra os interêsses comuns, a ação eficaz daqueles grupos de pressão a que acenávamos inicialmente.

O Projeto brasileiro segue êste caminho, regularizando a obra do artista intérprete e executante, como qualquer outra obra criativa, evitando, dêste modo, o perigo de desvios e deformações unilaterais.

Colocando em relêvo a simplicidade e a precisão de que deve revestir-se a expressão para ser bem compreendida, mas acrescentando que a simplicidade não convém à complexidade móvel da vida, leciona Alexandre $\mathrm{C}$. Angelesco (La Technique Législative en Matière de Codification Civile - Étude de Droit Comparé, Boccard, Paris, $1930)$, p. 10-11, que quanto mais moderno é um código, mais fluidos apresentará seus contôrnos, poucos precisos, permitindo à jurisprudência assegurar sua adaptação à vida. 
E acrescenta:

"Ainsi se pose un problème... qui nait de la difficulté de concilier "l'ordre et le mouvement"; nous croyons ici encore que des règles trop précises ne peuvent éxister en notre matière et que tout est une question "d'équilibre, de doigté".

A còté, et en liaison avec cette importante fonction de la loi, nous en rencontrons une seconde; celle de "refonte, de novation" législatif. La loi doit modifier ses procédés, changer son système lorsqu'il ne peut plus servir la vie. Aussi, l'objet de la technique législative ne portera pas seulement sur la rédaction des lois, mais aussi sur la manière dont se fera leur refonte, leur révision."

\section{Parte II.}

\section{A "arquitetura" do Projeto.}

\section{A Parte Geral.}

A analogia entre a arte de redigir e a arquitetura e a engenharia civil é tão banal que Rised Dickerson na abertura de seu clássico "Legislative Drafting", Little, Brown, Boston, 1954, hesita evocá-la.

Reconhece, por outro lado, ser tal a incompreensão existente sôbre a arte da redação, que seria injusto negar ao leitor o benefício de um paralelismo tão perfeito.

Resignemo-nos à... banalidade e procuremos apresentar uma perspectiva do Projeto.

Seus 198 artigos distribuem-se em três corpos principais: 60 na parte I, que, já vimos, abrange generalidades, atributos e limites do direito de autor; 59 na II, relativa às transmissões "inter vivos" e "causa mortis"; 79 na III, referindo-se aos órgãos de defesa, medidas cautelares e sanções.

Não existe razão para não considerar num projeto de lei a eurritmia que se manifesta em tôdas as "construções" jurídicas dignas dêste nome. 
Prát̃o já compreendera o sentido de profunda harmonia imanente a tôdas as coisas, quando afirmara que o belo ć o justo, elevando-se para contemplar do alto as diretrizes das disposições legais que buscam harmonizar os contrastes dos interêsses entre os homens.

Von IHering, agarrando e atualizando o conceito, não hesitou em incluir, entre os elementos que presidem à elaboração das leis do direito, a lei do belo juridico, ou seja, aquela lei que subordina a regra de conduta aos padrões estéticos da ordem, da simetria, do estilo e da proporção.

Comentando antes expressões, acrescenta o professor e magistrado brasileiro Mario Moacir Porto, Os Fundamentos Estéticos do Direito, Revista Forense, Rio de Janeiro, v. 229, 1970, p. 571:

“A estética, assim, é que fornece a medida do ordenamento legal, comportando-se como um metrônomo que acerta o passo da existência gregária ao compasso da norma disciplinadora. A imitação da natureza, ou a revelação da natureza através da intuição criadora é, em sentido amplo, a finalidade do Direito e o objeto da arte. No plano do Direito o justo se verifica através da oportuna adequação da regra às realidades humanas, do mesmo modo que no terreno da estética o belo se revela na eleição da forma que forneça a medida do justo na interpretação da natureza."

No Título I, os arts. 2-7 (Cap. I), subordinados, como o $1^{\circ}$, ̀̀ epígrafe $A$ Obra, fazem uma lista das obras protegidas, contemplam traduções e adaptações, obras coletivas, títulos das obras, enumeram as não protegidas, definem publicação e divulgação.

Os arts. 8-13 (Cap. II), Autoria, tratam da presunção de paternidade, pseudônimo ou sinal indicativo, presunçāo de titulariedade, obra sob "comissão", obra em colaboração indivisivel a obra composta. 
No Título II, Atributos, o art. 14 os separa em: "de ordem moral, que são perpétuos, inalienáveis, imprescritíveis e irrenunciáveis", e “de ordem pecuniária, que são relativos, divisíveis, temporários e transferíveis".

Tais premissas, verdadeiros pilares, tornam possível a fácil e harmoniosa construção do projeto, fixando com clareza, pelo que toca aos primeiros, os atributos essenciais do direito moral, direito à paternidade da obra, direito de inédito, direito de publicação, direito à integridade da obra, direito de correção, direito de arrependimento (arts. 15-18).

Desembaraça-se, assim, o caminho para a construção das regras relativas aos aspectos patrimoniais do direito, sempre mais complexos e controvertidos, separando a utilização sob forma corpórea da utilização sob forma incorpórea, especificando os limites de duração e traçando as regras pertinentes ao domínio público.

\section{Utilização sob forma corpórea.}

O Capitulo III - Direito Pecuniário - do Título II, se divide, por sua vez, em duas Seções : I - Utilização sob forma corpórea (arts. 19-24) e II -Utilização sob forma incorpórea (arts. 25-32).

São numerosas e diversificadas as formas de utilização da obra intelectual. Embora um Código não seja obra teórica, seus preceitos ganham em positividade, clareza e compreensão, quando obedecem a uma seqüência, mesmo porque a função de um Código não é apenas dispor, advertir, punir, mas, principalmente, instruir, prevenir, aconselhar, educar.

Por tal motivo, na enumeração e regulamentação das diversas formas de utilização, pareceu oportuna a divisão, já estabelecida na lei alemã, entre as formas corpóreas e as incorpóreas de utilização, regulando-se, entre as primeiras, os direitos de reprodução, de exposição e de distribuição, em suas generalidades, deixando as particularidades para cada espécie de obra, à Parte II do Código, arts. 76-116. 
Temos a seguir a determinação da natureza e conteúdo do direito pecuniário (art. 19), a definição do direito de reprodução (art. 20), e, sucessivamente, dos direitos de exposição (art. 21), exibição (art. 22), dỉstribuição (art. 23).

Nesta altura (art. 24) regulamentou-se o direito de seqüela ("droit de suite") : prerrogativa reconhecida de maneira irrenunciável e inalienável ao autor de obra de arte plástica, gráfica ou similar, "de haver da pessoa a que alienou a obra original e, posteriormente dos sucessivos adquirentes, uma participação sôbre o maior valor nas vendas feitas por meio de lances públicos ou com intuito especulativo", princípio já introduzido nas leis italiana, francesa, germânica, peruana e outras.

Não permaneceu insensivel o Projeto aos apelos dos artistas plásticos, que, preocupados com a incerteza do mercado nacional, temiam que um ônus nas sucessivas alienações pudesse provocar desinterêsse por parte dos eventuais compradores.

Buscou-se, então, atenuar os efeitos, fixando a participação em dois por cento calculados sôbre o produto da alienação, quando não inferior à soma de cinco salários mínimos vigorantes no Distrito Federal, e excluindo os casos de obras de arquitetura e de artes aplicadas.

Com isto outra coisa não faz o Projeto senão adaptar nossa legislação à Convenção de Berna, que o concede (art. 14 bis) até em maior extensão.

Mas, se o Projeto permaneceu aquém da Convenção, no que diz respeito à aplicação do princípio, caminhou muito além no que tange ao desenvolvimento e reafirmação da idéia em outras situações que apresentam certa semelhança.

Se o princípio é verdadeiro quanto à equiparação às obras de arte plástica, se a Convenção de Berna o reconhece e o aplica aos manuscritos originais dos escritores e compositores, nos quais - sejamos sinceros - mais que uma relação de direito de autor se denota o espírito de colecionador de relíquias famosas, não há razão para não estendê-lo a 
outras relações em que não o amor e a admiração dos colecionadores valoriza o "corpus mechanicum", mas o favor do público acompanha o sucesso de determinadas produções, premiando autores e artistas.

Aqui, sim, retornamos ao campo estrito do direito de autor e, então, não se compreende porque o sucesso dos autores e dos artistas deva favorecer extraordinàriamente apenas os empresários e os usuários da obra.

Por esta razão o Projeto, sempre que pode, não hesita em sugerir o mesmo princípio para outras relações. Assim, nas obras cuja utilização não permita a imediata determinação dos contatos com o público (como ocorreria com as cópias de uma edição gráfica), e o exemplo que logo se apresenta é o da obra cinematográfica, procurou-se suplementar a remuneração do autor e dos artistas, que não tenham feito contratos em base percentual, com um adicional, quando seus trabalhos ou execuções tenham um sucesso além do previsto.

Dir-se-á que por essa forma se estabelece uma discriminação injusta, visto que ninguém se preocupa em socorrer o empresário em caso de fracasso.

Encontrâmo-nos certamente face a interêsses que têm pontos de colisão. Mas procura-se justamente um ponto de equilibrio, sem prejuízo de quem quer que seja, e que, de qualquer maneira, poderá ser retificado, por meio da experiência adquirida.

\section{Utilização sob forma incorpórea.}

É objeto da Seção II, com oito artigos relativos ao direito de recitação pública (art. 25), direito de execução e representação (art. 26), intuito de lucro (art. 27), direitode autor na radiodifusão (art. 28), direito de comunicação das execuções ou representações (art. 29), fixação das execuções ou representações (art. 30), independência e alcance 
dos direitos exclusivos (art. 31) e direito de locação de obra ou de reprodução (art. 32).

Ainda aqui o Projeto propõe algumas inovações fundamentais.

A primeira, por ordem de importância, é, indubitàvelmente, a que tem por objeto fazer de tal modo que, em qualquer oportunidade, tôdas as execuções ou representacõ̃es públicas, ainda que sem finalidade lucrativa, direta ou indireta, dependam do pagamento prévio da retribuição (art. 27, "caput").

A êste princípio deverão submeter-se os particulares. os "clubs", as emprêsas de radiodifusão e de televisão, a Igreja, o Estado, etc., pondo-se fim à situação de "terra de ninguém", que é a dos "pequenos direitos".

Quando um Fulano toma a iniciativa de um festival, de uma festa popular, de uma reunião dançante ou qualquer outro espetáculo público, com o mais louvável, altruista e benemérito dos intuitos beneficentes, não lhe passará nem mesmo pela antecâmara do cérebro exigir dos fornecedores de bebidas e alimentação, do padeiro, dos pintores, eletricistas, encanadores, mecânicos, motoristas, operários, etc., aos quais se dirigirá, qualquer prestação gratuita de mercadorias ou servicos.

E quando pretenda uma contribuição, um óbulo, um. donativo, lançará, com voz trêmula de emoção, um apêlo, e, com louvável compreensão cristã, resignar-se-á a uma recusa.

Com o autor e com o artista intérprete e executante acontece justamente o contrário.

E tão fácil colocar um disco num gramofone e transmitir seus acordes (ou desacordes) por meio de impiedosos altofalantes, aos sofredores tímpanos de quantos passem pelas proximidades, que não se preocupam absolutamente, os organizadores de tais saturnais de beneficência, em avisar o autor, o artista, ou a sociedade que os representa, de que pretendem desfrutar suas obras. . 
Chegam até a reagir com impropérios às veleidades de uma cobrança, sob a peregrina alegação de que prestam um favor aos autores e aos artistas, divulgando suas produções.

Pois bem: a composição, a execução, o canto são o pão do autor e do artista, é trabalho sacrossanto, como é sacrossanto o trabalho do pintor, do eletricista, do encanador, do mecânico e do motorista, e se a êstes, com muita educação, se pedem seus préstimos, não há razão porque não deva merecer a mesma benevolência uma solicitação de autorização por parte de autor ou do artista para a execução de suas obras.

Se o ministro do culto religioso paga os tapetes, os ornamentos, as velas, as flores com que atavia o seu templo, a energia elétrica que consome, o telefone que utiliza, não se percebe porque o compositor e o artista intérprete merecem menos respeito que o tapeceiro ou o florista.

$\mathrm{O} \S 1 .^{\circ}$ enumera seis casos que, além do pagamento de ingresso, caracterizam o intuito de lucro, e o $\S 2 .^{\circ}$ responsabiliza solidàriamente para o pagamento do direito de autor os empresários, os proprietários, representantes legais de cstabelecimentos, entidades e organismos onde a obra, por qualquer modo, tenha sido utilizada.

Oferece, de tal modo, um critério altamente moralizador, evitando que tais pessoas, por pouco caso ou indiferença, venham a proporcionar, embora involuntàriamente, apôio aos violadores dos direitos alheios.

\section{Limites do direito de autor.}

O Título III da Parte I do Projeto divide-se em dois Capítulos: I — Duração (arts. 33 - 43) e II - Restrições e Domínio Público (arts. $44-60$ ). 


\section{Parte III.}

Transmissão dos direitos.

Admitida a contribuição do artista intérprete ou executante como obra em si mesma, torna-se fácil erguer a cúpula do corpo central do edifício, a Parte II do Projeto, no que se refere ao aspecto mais importante do ponto de vista legislativo, isto é, a cessão dos direitos pecuniários, sôbre oito colunas formadas pelas obras principais:

1. gráfica, fonográfica ou fonovisual (arts. 76 a 84);

2. dramática (85);

3. de arte plástica $(86-88)$;

4. fotográfica $(89-93)$;

5. jornalística ou periodística $(94-95)$;

6. do artista intérprete ou executante $(96-101)$;

7. cinematográfica $(102-112)$;

8. radiofônica ou audiovisual $(113-116)$.

É formada, esta cúpula, de uma referência indispensável à transmissão causa mortis, e das disposições mais completas relativas à transmissão inter vivos.

Temos, portanto, um agrupamento de disposições genéricas -- que abrangem tôdas as obras indistintamente, desembaraçando as seções específicas - que não devam referir-se às particularidades das categorias de cada uma delas, obtendo dessa maneira maior harmonia no conjunto.

Trata-se do Capítulo I, Cessão de Direitos, dividido em duas Seções: a primeira contendo Peculiaridades, que começa com o

“Art. 63 - Requisitos - As cessões relativas à utilização do direito de autor, do artista intérprete ou executante, que serão sempre por escrito, não se presumem gratuitas, e devem ser interpre- 
tadas estritamente com a ressalva da participação proporcional fixada nesta lei ou a ser fixada pelo CONDAC, compatível com a natureza da obra."

O art. 64 declara nula a cessão global das obras futuras, salvo em caso de compromisso até o máximo de cinco, em gênero determinado, num prazo de cinco anos, a contar da data do registro de contrato.

De importância fundamental é o

Art. 65 - Objeto da cessão de direito de utilizar - Pode ser objeto de cessão a utilização de uma, alguma ou tôdas as faculdades inerentes ao direito pecuniário do autor desde que ao mesmo seja ressalvada uma participação proporcional, compativel com a natureza da obra.

$\S 1^{\circ}$ - $O$ direito de utilização simples confere ao cessionário a faculdade de usar a obra, concorrentemente com o autor ou com outros cessionários, na conformidade dos poderes que lhe foram atribuidos.

$\S 2 .^{\circ}$ - O direito de utilização exclusiva confere a faculdade de utilizar a obra, com exclusão de qualquer outra pessoa, inclusive o autor, e de outorgar direitos de utilização simples."

0 art. 67 fixa os requisitos do instrumento de cessão, estabelecendo que, sem prejuízo das cláusulas obrigatórias previstas pelo Código, relativas às diferentes espécies de contratos, além dos requisitos usuais, deverão ser mencionados:

I - a natureza e a finalidade dos direitos cedidos;

II - a utilização que o cessionário dará à obra, o prazo para a sua publicação e reprodução por qualquer processo;

III — se a obra cedida se destinar à reprodução: 
1. o número exato dos exemplares gráficos, fonográfico ou de qualquer outra natureza a serem produzidos;

2. se o contrato tiver por objeto mais de uma tiragem, o número dos exemplares da subseqüente, presumindo-se ser apenas uma na falta de estipulação;

3. o número de exemplares destinados ao autor e a distribuição gratuita em cada tiragem;

4. o prazo para colocação dos exemplares no comércio e os prazos relativos às tiragens sucessivas, se objeto do contrato;

5. o preço por que ao público serão vendidos os exemplares da obra;

6. a duração do contrato esgotada ou não a tiragem;

IV - a remuneração do autor, a forma e a época do pagamento;

V - a cláusula de exclusividade do direito de utilização presumindo-se sua inexistência, quando não mencionada ou quando não fixada a sua extensão;

VI - dependendo da natureza da utilização, o intérprete ou intérpretes da obra."

Seguem disposições relativas aos elementos complementares do contrato, à extensão da cessão, à proibição da transferência, por parte do cessionário, sem consentimento por escrito do autor, dos direitos adquiridos, bem como das matrizes, modelos, "clichés", negativos, etc.

A segunda das mencionadas Seções refere-se aos direitos e deveres, seja do autor, seja do empresário.

São direitos e deveres genéricos que, todavia, para evitar equívocos, merecem ser enumerados e catalogados.

Tomemos, por exemplo, o 
“Art. 72 -.. Deveres do empresário -- Constituem deveres do empresário, como tais considerados os que se dedicam à fixação, reprodução, ou qualquer utilização da obra intelectual, com intuito de lucro direto ou indireto, sem prejuízo dos demais previstos nesta lei:

I - reproduzir, distribuir e colocar à venda, ou executar a obra pela forma convencionada mencionando, conforme o caso, o nome do autor, seu pseudônimo, sinal indicativo, do tradutor, do adaptador, compilador, autor da versão, do artista intérprete ou executante, ou tratar-se de obra anônima;

II - garantir à obra uma exploração permanente e contínua, e a difusão comercial na medida das necessidades do escoamento do estoque;

III - pagar ao autor prèviamente, ou de três em três meses, a retribuição estipulada, aplicando-se em caso de atraso, a correção monetária;

IV - devolver ao autor, salvo impossibilidade de ordem técnica, o original da obra pelo qual ficará responsável;

$\mathrm{V}$ - dar preferência ao autor da obra intelectual para a aquisição de exemplares ainda existentes, das matrizes, moldes e similares;

VI - prestar contas anualmente com indicação dos exemplares fabricados, do número em estoque, dos inutilizados ou destruidos, por caso fortuito ou de fôrça maior e do montante dos direitos pagos ao autor, facultado a êste, no caso de dúvida, o exame da escrituração."

Seguem disposições relativas aos direitos do empresário, à sua morte, à liquidação do ativo.

Abusaria da boa vontade da Direção da Revista da Sociedade Italiana dos Autores e Editores e da paciência de seus leitores se nesta projeção panorâmica me detivesse cada uma das obras regulamentadas pelo Projeto. 
Não posso, todavia, deixar de aludir ao fato, que certamente levantará protestos, de abarcar em uma única seção, a regulamentação das edições de obras gráficas, fonográficas ou fonovisuais.

Mas, sem prejuízo da observância às particularidades de cada uma destas modalidades, não há razão por que não se possa redigir um

"Art. 79 - Deveres do editor - Além dos demais previstos, no que couber, são deveres do editor:

I - editar ou reeditar a obra dentro do prazo estabelecido;

II - devolver dentro do prazo de cento e vinte dias com resposta favorável ou não os originais que lhe foram confiados para estudo;

III - numerar sucessivamente os exemplares de cada tiragem, inclusive os destinados ao autor ou à divulgação da obra;

IV - não produzir exemplares em número superior ou inferior à tiragem contratada;

$\mathrm{V}$ - executar sem interrupção as tiragens sucessivas a que se tenha obrigado de forma a que não venha faltar ao comércio.

$\S 1 .^{\circ}$ - O autor tem sempre a faculdade de rubricar os exemplares de sua obra posta no comércio, só dispensando a respectiva numeração quando houver estipulação expressa.

$\S 2 .^{\circ}-$ Sejam quais forem as condições contratuais, o editor é sempre obrigado a facultar ao autor o exame da respectiva escrituração e informá-lo sôbre o estado da edição."

Por outro lado desce o art. 80 em particularidades no resguardo dos direitos do editor fonográfico ou fonovisual, reconhecendo-lhes, além daqueles já previstos: 
I - exigir uma compensação pela utilização com intuito de lucro, do fonograma, fonovideo e semelhantes, ou suas reproduções;

II - opor-se a que qualquer utilização do fonograma e semelhantes seja efetuada em condições que acarretem prejuizos aos seus interêsses industriais.

$\mathrm{E}$ porque não poderia ser relativa às três modalidades supra indicadas uma disposição como a do

“Art. 81 - Dados obrigatórios - Não poderão ser lançados ao comércio os exemplares de que não constem, em forma e lugar visíveis :

I - o título da obra, autoria e, se fôr o caso, nome do artista intérprete ou executante;

II - a menção "direitos reservados" ou sua abreviatura: "D.R.", seguidas pelo símbolo: "C" ou "P", no fonograma quando êste fôr protegido, devendo as obras caídas no domínio público mencionar a circunstância;

III - nome e enderêço do titular do direito;

IV - data da edição ou da fixação;

V - número ordinal a que corresponde a tiragem;

VI - número do exemplar na sua série;

VII - em se tratando de versão ou tradução, o nome do tradutor e o título da obra no idioma original;

VIII - nome ou razão social e enderêço do editor e do impressor;

IX - número de exemplares impressos;

$\mathrm{X}$ - local e data em que terminou a impressão;

XI - menção da autorização do Condac para as fixações, e reproduções no território nacional de fonogramas, matrizes, moldes e semelhantes provenientes do exterior"?

Seguem disposições relativas à remuneração e ao registro dos percentuais quando seja esta a forma escolhida para o pagamento. 
Esta preocupação, de não emaranhar as regras relativas e cada uma das obras com disposições que não sejam específicas, leva, naturalmente, à separação de normas que sejam relativas à fase terminativa, nem sempre cuidadosamente regulamentada, apesar de sua indiscutível importância.

A tanto provê o Capítulo VIII, que estabelece uma diferença entre resoluçẫo (art. 117) e a rescisão do contrato (arts. 118 - 119), com enumeração de sete hipóteses no primeiro e seis no segundo caso.

\section{Parte IV.}

Tutela dos direitos. órgãos, medidas cautelares, sanções.

A Parte III do Projeto, de encerramento, correspondendo à epígrafe supra, é a mais polêmica, ou pelo menos a que levantou e continuará levantando maiores oposições e resistências.

o Projeto alicerça suas arquitraves em uma galharda proteção da obra intelectual, até contra o próprio autor, procurando envolvê-la numa rêde de malhas estreitas, esforçando-se por desvincular-se do conceito, que já deveria estar ultrapassado, da finalidade de lucro na sua utilização.

Bem se compreende, por isto, que encontre resistências encarniçadas.

Um grave inconveniente é o da proliferação das sociedades de direitos de autor. Temos nada menos que seis: a sbat, a UbC, a SBACEM, a SADEMBra, a SiCAM e a Socimbro.

Em 29.9.1966, antecipando-se em parte ao que seria a orientação do Projeto, os representantes da SBAT, da UBC, da SBACEM e da SADEMBRA constituiram um escritório central, o "Serviço de Defesa do Direito Autoral - Escritório de Cobrança", cujo objetivo, nos têrmos do art. $90^{\circ}$ do respec- 
tivo estatuto, é levar a efeito todos os serviços de cobrança e administração, por meio de quatro membros, um de cada uma das sociedades pactuantes.

De qualquer modo os inconvenientes são graves. A percepção custa caro - nota Marcel Plaisant - e exige ao menos para certas obras, forte rede local de representantes, e para tudo, uma organização administrativa que estabeleça os contratos com os usuários, receba e distribua. A existência de duas ou mais sociedades aumenta, evidentemente, as despesas e complica as atribuições dos usuários.

Acrescenta Hermano Duval, Direitos Autorais nas Invenções Modernas, Andes, Rio, 1956, p. 379, a disparidade dos critérios na distribuição dos direitos arrecadados entre os membros de uma sociedade, a diversidade de critérios na estipulação e cobrança dos preços unilateralmente fixados em cada tabela, o favoritismo a que conduz os usurários responsáveis pelos direitos de autor (chefes de orquestra, discotecários de emissoras, etc.) na escolha dos repertórios, em detrimento dos compositores das sociedades preteridas; a confusão estabelecida entre os usuários dos repertórios oferecidos pelas diversas sociedades.

Inegável é o interêsse do Estado no contrôle do modo em que são distribuídos os direitos de autor, uma vez que não se trata de sociedades que tenham finalidade lucrativa.

Complementa Mario Fabiani, "Le societa di autori. Funzioni e Natura Giuridica", in "Rivista delle Società", Milano, Giuffré, ano Ix 1-2, Jan., Abril 1964, p. 36, que embora administrando direitos de natureza patrimonial, as sociedades de autores destinam-se, em última análise, a facilitar o desenvolvimento e a difusão da arte e da cultura, o que corresponde a um interêsse também do Estado, acrescentando:

"Em virtude de tais considerações, foi determinada, em vários países, uma intervenção do Estado no que diz respeito às sociedades de autores, que se apresenta ou sob a forma de autoriza- 
ção para o exercício, ou sob forma de contrôle das suas atividades. A essa atividade reconheceuse, às vêzes, nas leis e na jurisprudência de cada um dos países, caráter de utilidade ou de interêsse público."

É necessário, porém, que se faça justiça às sociedades brasileiras de direito de autor: proteger êste direito num país imenso, cuja população, relativamente escassa, se agrupa em parte em grandes cidades densamente povoadas, enquanto o restante se espraia por espaços sem fim, com insuficientes vias de comunicação e acesso muitas vêzes sacrificadíssimo, reclama organização e despesas que ascendem a percentuais verdadeiramente absurdos.

Uma razão a mais, de qualquer modo, para reduzir o seu número, ou para reconduzí-las ao princípio racional da especialização: uma sociedade para cada categoria ou para categorias próximas de obras intelectuais, embora não fechando a porta à organização de um escritório central ou de uma rêde de postos de percepção comum.

Como resolver o problema no âmbito do projetado Código?

Pareceu ao autor do anteprojeto que o melhor caminho seria o de centralizar as atribuições das sociedades de autor em um órgão estatal: o ECA - "Escritório Central de Arrecadação".

Após longas discussões reconheceu Sua Excelência que o ECA tornaria demasiado burocrática e ainda mais onerosa a percepção.

Esta providencial transigência obrigou, todavia, a uma completa modificação de orientação.

Foi então submetida a um total reordenamento a organização das sociedades de tutela e de percepção de proventos de direitos de autor, com regulamentação minuciosa e com um regime de contrôle que não admite desvios 
na distribuição efetiva e equânime dos direitos aos verdadeiros titulares, moralizando definitivamente um setor tão controvertido.

O Projeto dedica a mais acurada atenção à atividade que tais sociedades desenvolvem, que transcende muito os estreitos limites do interêsse particular, sem qualquer füscalização, aliás, por parte dos organismos públicos.

'Tornaram-se no mundo atual - observa VALERIo DE Sanctis, Contratto di Edizione, Giuffrè Milão, 1965, p. 304 - organismos quase indispensáveis à percepção, ao contrôle e à repartição dos proventos, especialmente com referência às obras de espetáculo público ou musicais:

"Privado do concurso eficiente do instrumento das sociedades de autores, o autor isolado, como os seus herdeiros e os seus subrogados por atos entre vivos, e especialmente os editores de música, não poderiam, ou então só conseguiriam com grande dificuldade, exercer os direitos que lhes são reservados pela lei e vigiar sôbre a pública utilização da obra. Por outro lado, sem as sociedades de autores, os usuários públicos, especialmente os de vastos repertórios musicais, não estariam em condições de localizar fàcilmente os titulares dos direitos, nem solicitar e obter, conseqüentemente, as autorizações legalmente necessárias."

Explica-o bem Robert Plaisant, Les Sociétés d'Auteurs, no mencionado Juris Classeur, fasc. 12, 1965, p. 3:

"Cumpre aditar que os autores ficam em situação de inferioridade cada vez mais assinalada com relação aos usuários. Èstes podem ser poderosas companhias privadas, por exemplo em matéria de discos ou de cinema, ou outras menos poderosas mais talvez, conforme o caso, menos 
instruídas a respeito das obrigações relativas ao direito de autor. Pode tratar-se mesmo de organismos públicos ou semi-públicos; é o que ocorre freqüentemente em matéria de radiodifusão e os contratos tendo por objeto o direito de autor não são necessàriamente mais fáceis de se concretizarem, estando submetidas as entidades a regras financeiras e a cuidados de interêsse geral que limitam sua liberdade."

Completa o quadro Mario Fabiani, recordando que a ação de ditas entidades não se restringe apenas ao campo patrimonial. Será certamente esta sua atividade e o interêsse mais geral: a proteção " $d a$ propriedade intelectual considerada, no seu conjunto, como patrimônio comum do país."

Mas justamente por isto, "a sociedade persegue. . finalidades de encorajamento da produção artística e de difusão da arte e da cultura, finalidades que assumem um perfil nìtidamente publicístico e que o Estado assumiu, atribuindo-as, para a sua realização, a uma entidade para tal fim constituída. Nem pode ter relêvo o argumento de que a sociedade tenha surgido originàriamente com estas mesmas finalidades de proteção do direito de autor, como entidade privada; é sabido que o Estado, com próprias manifestações de vontade, pode considerar de sua competência atividades que, embora surgidas graças à iniciativa privada, relacionam-se a uma finalidade de interêsse público."

Se tivermos presente, finalmente, que tais sociedades se aliam no plano internacional não apenas por meio de acôrdos de mútua representação, mas reunidas na Confédéıation Internationale des Sociétés d'Auteurs et Compositeurs (CISAC), bem se compreenderá que esta fiscalização é de importância fundamental mesmo pelo que se relaciona ao bom nome da Nação no âmbito internacional. 
Resultarão então claras as intenções do Projeto quando, admitindo a permanência das sociedades, dedica-lhes os arts. 120 a 136, indicando suas finalidades (art. 121), fixando os requisitos para seu funcionamento e regulando a participação dos membros (arts. 123), não permitindo a nenhum titular de direito de autor ou de direitos conexos ser membro de mais de uma sociedade, salvo como decorrência da diferença do gênero de suas obras ou atividades, consentindo a vinculação a uma nova sociedade, e o elenco de suas obras nas relações respectivas, apenas após o cancelamento nas relações anteriores da sociedade de que se desvincule, etc...

O art. 125 estrutura a organização das sociedades, merecendo relèvo o

“§ 6. ${ }^{\circ}-$ Os votos serão exercidos pessoalmente, não permitidas procurações, podendo ser atribuído a cada sócio até o máximo de quatro votos, na conformidade da contribuição do seu repertório à arrecadação durante o exercício imediatamente anterior, devendo para êsse fim a Assembléia Geral fixar o número de votos para cada exercício, a vigorar no ano seguinte, podendo o número ser reduzido, em face da diminuição do provento da arrecadação do repertório do associado."

\section{A percepção dos direitos.}

Numerosas alterações foram propostas com referência a esta matéria de importância fundamental, objetivando racionalizar e simplificar o pagamento dos proventos devidos ao autor e ao artista.

Procurou-se atribuir, quando necessário, a uma determinada pessoa a centralização dos pagamentos de direito de autor, escolhendo-se sempre aquela cuja natureza de 
funções indica como a mais adequada para esta tarefa: o empresário.

E ainda uma vêz, a título de exemplo, invocaremos a obra cinematográfica, que, justamente porque é uma das mais complexas, presta-se melhor à discussão. São freqüentes as recriminações dos concessionários de salas de cinema pelo que se refere ao obstáculo que sofrem seus espetáculos, em virtude da reclamação do autor de uma música, apenas de importância secundária, que é transmitida com a projeção do filme.

Do ponto de vista teórico, não há como impedir ao autor de fazer valer seus direitos, ainda que pelo meio mais enérgico, a suspensão do espetáculo.

A medida não satisfaz o autor, que não pode acompanhar a cópia cinematográfica em tôdas as suas peregrinações, constitui um pesadêlo para o concessionário, e pode trazer aborrecimento ao público, muitas vêzes desiludido em sua expectativa de assistir ao filme de sua predileção.

Mas não se pode esquecer que o autor e o artista não são os únicos interessados naquela comunicação ao público, de modo que o exercício de seu direito pode acarretar prejuízo aos interêsses de numerosas outras pessoas.

Ora, os inconvenientes derivados da utilização, ainda que não autorizada, de obras coletivas complexas, em que intervenham numerosas pessoas, como fonogramas de orquestrações, obras cinematográficas, obras transmitidas por meio de radiodifusão ou da televisão, podem ser minorados. O objetivo se alcançará desde o momento em que ao produtor ou promotor ou responsável pela sua organização, distribuição, acesso ao público, sejam conceridas, além das atribuições que a natureza mesma de suas funções indicam, uma outra, que delas é decorrente: centralizar a responsabilidade para o pagamento, não apenas da retribuição imediata de todos os colaboradores, mas também dos ulteriores pagamentos a que tenham direito. 
Teremos, então, uma pessoa a que se possam dirigir os interessados: alguém que não pode, ou não deve ignorar o lugar para onde serão enviadas as cópias, alguém que estará, ou deverá estar em condições de dizer onde e por quem são utilizadas, alguém que, com maior visão, por meio de contratos ou de cláusulas oportunas, saberá determinar com precisão direitos, deveres e responsabilidades.

Procurando prevenir que autores e intérpretes, sempre incapazes de defender seus direitos patrimoniais, continuem os eternos vendilhões de seus direitos a trocá-los por um prato de lentilhas, o projeto fulmina de nulidade a cessão aos produtores que ultrapasse $20 \%$ do total que perceberem, no caso de utilização de gravação em fonogramas, videogramas, obras cinematográficas e nas de transmissão ou retransmissão de obra em que sejam interessados, ao mesmo tempo, o autor, o artista intérprete ou executante, o produtor fonográfico ou cinematográfico e a entidade de radiodifusão sonora ou visual. O remanescente deverá ser reconhecido aos autores, intérpretes e executantes, na proporção de sessenta por cento aos primeiros, e quarenta por cento aos segundos (art. $31, \S \S 3 .^{\circ}$ e $4 .^{\circ}$ ).

o Projeto transigiu ao admitir o domínio público remunerado, objeto de críticas e de objeções bem fundadas.

Mas uma observação prática o conduz a não manter uma atitude irredutível a êste respeito.

Qualquer pessoa que se dirija a uma livraria para adquirir obras literárias dificilmente se aperceberá de qualquer diferença de preço entre as publicações de obras caídas no domínio público e as que ainda rendem proventos ao autor, assim como será vã a esperança de pagar menos pelo ingresso em um cinema ou um teatro que exibam películas ou dramas teatrais baseados em romances escritos no século passado.

A conclusão é que o domínio público favorece apenas o empresário. 
Por que não admitir, então, como propõe o Projeto, art. $60, \S 1 .^{\circ}$, em medida muito modesta, o pagamento de uma terça parte da importância que, normalmente, deveria ser paga ao titular de direito de obra similar não caída em domínio público?

O montante irá para o Fundac, isto é, o Fundo de Direito de Autor e Direitos Conexos, que procurará entre suas muitas atribuições, proteger e ajudar mulher e fillos dos autores falecidos, em suas necessidades mais imediatas.

Atente-se a que a medida, com moderação, favorece os autores vivos, não permitindo que a concorrência dos autores falecidos se exerça sem qualquer limitação. .

\section{Sanções e defesa.}

Eis-nos chegado à parte, a meu ver, mais importante do Projeto.

Em matéria de repressão às infrações de direito de autor não é possivel não reconhecer a completa ausência de progresso nos últimos decênios, em todo o mundo, seja por parte das leis, seja por parte da doutrina e, conseqüentemente, por parte da jurisprudência.

A razão é das mais curiosas: os especialistas de direito de autor, salvo raríssimas exceções, não the aprofundaram o estudo, dado que, em geral, não apreciam investigações de natureza criminalística.

Os penalistas, por outro lado, não têm simpatia por um tema que crêem de natureza essencialmente privatística.

Sua sensibilidade não tocou o ponto fundamental que é a circunstância de que as vítimas sofrem o maior dano não na perda de algum valor móvel de sua propriedade, como sucede em geral, mas na diminuição da possibiliclade de lucros legítimos a que suas obras deveriam dar lugar.

Tullio Ascarelli, Teoria della Concorrenza e dei Immateriali, Giuffrè, Milão, 1956, p. 219, soube captar a quase evanescente linha demarcatória entre o interêsse material 
do autor sôbre o seu produto intelectual, e outras vantagens, também materiais, mas ilícitas quando não autorizadas, que de sua obra podem retirar outras pessoas:

"Il ricorso alla proprietà nella configurazione del diritto assoluto di utilizzazione sui beni immateriali indica perciò solo le caratteristiche formali del diritto: non deve far dimenticare la differenza e anzi la contrapposizione tra cose materiali (e energie) da un lato e creazioni intellettuali dall'altro; non deve far dimenticare come nella disciplina dei beni immateriali, l'interesse tutelato sia quello della probabilità di guadagno conseguibile mediante l'estrinsecazione della creazione intellettuale in un'attività con terzi e non già quello alla appropriabilità delle dirette utilità di una cosa.

Se strutturalmente, quando sia riconosciuto un diritto assoluto di utilizzazione, possiamo far ricorso al concetto di proprietà, funzionalmente ci troviamo sempre di fronte alla tutela di una probabilità di guadagno e poco importa, è ovvio, che la persecuzione di un guadagno costituisca o meno, nel caso, l'intento che ha animato il soggetto nella creazione."

Já observara, à p. 207-208, que o que é proibido é justamente a utilização da criação atual e por isto a obrigação de abstenção dos outros frente ao titular do direito absoluto de utilização.

E, chegando ao ponto:

"L'illecita utilizzazione viene, nella maggior parte dei casi, anche penalmente repressa e si noti come la speciale sanzione penale trovi la sua giustificazione nell'impossibilità di far invece capo a quella tutela penale che socorre per le cose materiali e energie, tutela che si coordina 
innanzi tutto con quel possesso e quella esclusività di possesso che invece non si può riscontrare per le creazioni intellettuali."

As grandes oportunidades que a técnica moderna oferece aos defraudadores do direito de autor, e o conseqüente aumento extraordinário das transgressões nesta matéria, demonstram que é necessário reforçar as providências de ordem civil, em geral lentas, dispendiosas, inseguras, com providências bem mais enérgicas e eficazes de ordem penal.

Há algum tempo contou-me um ilustre magistrado de uma importante cidade turística, um caso que poderia ser considerado típico de certa mentalidade infelizmente bastante difundida.

O concessionário de uma "boite", recebendo a notificação de uma sociedade de direitos de autor, dispensou músicos e cantores, substituindo sua atividade artística por meio de discos fonográficos, crendo que de tal maneira evitaria o pagamento.

Informado de que a execução musical em público, por meio de discos, não o exoneraria do desembôlso, deu-se pressa em gravar música irradiada por rádio em fita magnética.

Recebida a terceira notificação. - preferiu fechar o estabelecimento a pagar uma importância que consistiria numa percentagem ridícula em relação às despesas gerais...

Todo o aparêlho da Polícia e da Justiça tem sido sempre operante e pouco eficiente no que se relaciona à punição de semelhantes "gangsters" do direito de autor.

Substituindo o revólver e a metralhadora ligeira por um sorriso sardònico, sem o risco de enfrentar policiais armados, ou as barras de uma prisão, desafiam, demasiadas vêzes impunemente, comissários, fiscais, delegados de polícia e tribunais, na certeza de que, entre a punição de uma imaginária pena de prisão até seis meses, e uma multa irrisória, nenhum magistrado hesitaria em propender por esta última alternativa. 
Năo se pode admitir que se perpetue semelhante sistema. A fiscalização do pagamento dos direitos de autor, através de aprovação dos programas pela autoridade da Policia, conquista importante do velho decreto n. $^{\circ} 22.337$, de 10-1-1933, não pode absolutamente ser descurada, enquanto não se descobrir um sistema mais eficiente e mais completo.

Ao contrário: deveria ser reforçada com punições àqueles que, por comodidade, falta de escrúpulo ou omissão culposa ou dolosa, descuidem-se de cumprir o seu dever.

Resultará, porém, vã ilusão buscar enfeixar num cêrco bem delimitado as figuras dos delitos de falsificação, de defraudação, de usurpação, de furto próprio e de furto impróprio, de edição, execução ou representação não autorizada, reprodução com modificação de título, supressão ou substituição do nome do autor, etc., etc.

Os contornos são indefinidos, as figuras freqüentemente se entrepenetram a tal ponto que, apesar de todos os esforços não parece que os próprios especialistas franceses sintam-se satisfeitos com as modificações introduzidas pela lei de 11-3-1957.

č pelo menos o que dá a entender a redação categorizada da Révue Internationale du Droit d'Auteur, abril de $1958, \mathrm{n}^{\circ} 19$, totalmente consagrada à matéria, in La Procédure et les Sanctions, p. 455-457:

"Les textes nouveaux n'apportent aucune précision quant aux éléments du délit de contrefaçon: le système suivi par la jurisprudence dans la période autérieure ne semble pas devoir être bouleversé."

Reconhecendo a importância das duas inovações introduzidas pela mencionada lei, o delito de hábito de contrafação e a reincidência no delito de hábito de contrafação, o Projeto brasileiro não se preocupa em especificar as denominações de cada uma das múltiplas e cambiantes modali- 
dades de delitos possíveis, mas sim em fazer um rol das diferentes infrações, submetendo-as a penalidades mais graves (um a três anos de reclusão e pagamento de trinta a cem dias-multa), quando resultem de propósito deliberado de causar prejuízo ao autor ou ao artista, e menos graves quando a eventualidade seja caracterizada mais por culpa do que por verdadeiro dolo (detenção de 15 dias a dois anos ou pagamento de vinte a sessenta dias-multa).

Bem se compreende que, com semelhantes dispositivos, com o contrôle rigoroso que se propôs do recolhimento e da distribuição dos proventos relativos ao direito de autor, o Projeto não pode contar nem com a simpatia dos empresários nem com a de parte das direções das próprias sociedades de direitos de autor, que, todavia, sentem-se cada vez mais emaranhadas numa situação insustentável como decorrência da falta de uma política uniforme relativa ao direito de autor.

O Govêrno brasileiro, cuja autoridade e popularidade foi confirmada por uma impressionante manifestação de apôio nas eleições de 15 de novembro de 1970, encontra-se em posição mais do que favorável para empreender uma reformulação que o colocaria à testa de um movimento destinado a refletir-se fatalmente nas outras Nações da América do Sul.

Chegará o navio Projeto do Código de Direito de Autor a bom pôrto? Quando? "Questo non si sa”, para dizê-lo com a canção popular.

Aos autores do Projeto - que não fazem parte de nenhum grupo interessado - tendo procurado manter-se eqüidistantes de todo aspecto polêmico, cabe o consôlo de haver feito tudo para cumprirem seu dever.

Nutrem a esperança de que seu trabalho não tenha sido vão.

Mas. " "habent sua fata propositiones legum" 